\title{
Relationships between Cultural Adaptation and Immigrants’ Well-Being
}

\author{
Érica Henke Garcia Martinet ${ }^{1}$ \\ Bruno Figueiredo Damásio² \\ ${ }^{1}$ Universidade Federal do Rio de Janeiro (UFRJ) e Universidade Estácio de Sá (UNESA) - Rio de Janeiro, Rio de Janeiro, Brasil \\ ${ }^{2}$ Universidade Federal do Rio de Janeiro (UFRJ) - Rio de Janeiro, Rio de Janeiro, Brasil
}

\begin{abstract}
The present study aimed to evaluate the predictive relationship of socio-demographic variables, cultural adaptation and hope on general well-being (GWB), subjective (SWB), social (SoWB) and psychological (PWB) and in the meaning of life. The participants consisted of 108 immigrants. The instruments used were: bio sociodemographic questionnaire, Mental Health Continuum - Short Form, Dispositional Hope Scale, Acculturation Measures and Meaning of Life Questionnaire. In general, only sociocultural adaptation showed a positive predictive relationship with all types of well-being studied, nonetheless this measure presented a negative predictive relationship regarding the presence of meaning in life. Psychological adaptation was predictively and positively related only to SWB. The perception of cultural distance negatively affected SoWB. The presence of meaning was also negatively predicted by the type of immigration and age. The search for meaning was negatively predicted only by income. The results are important for a better understanding of factors that influence the experience of immigrants in Brazil. Keywords: Brazilian immigration; sociocultural factors; refugees; positive psychology.
\end{abstract}

\section{Relações entre Adaptação Cultural e Bem-Estar de Imigrantes}

\begin{abstract}
Resumo
O presente estudo objetivou avaliar a relação preditiva de variáveis sociodemográficas, adaptação cultural e esperança sobre o bem-estar geral (BEG), subjetivo (BES), social (BESo) e psicológico (BEP) e no sentido de vida. Os participantes consistiram em 108 imigrantes. Os instrumentos utilizados foram: questionário biossociodemográfico, Mental Health Continuum - Short Form, Escala de Esperança, Acculturation Measures e Questionário de Sentido de Vida. De forma geral, apenas a adaptação sociocultural apresentou relação preditiva positiva com todos os tipos de bem-estar estudados, além de uma relação preditiva negativa com a presença de sentido de vida. A adaptação psicológica relacionou-se preditiva e positivamente apenas com BES. A percepção de distância cultural afetou negativamente BESo. A presença de sentido de vida foi negativamente predita pelo tipo de imigração e idade. A busca por sentido foi negativamente predita pela renda. Os resultados são importantes para a melhor compreensão de fatores que influenciam a vivência de imigrantes no Brasil.

Palavras-chave: imigração brasileira, fatores socioculturais, refugiados, psicologia positiva.
\end{abstract}

\section{Relaciones entre la Adaptación Cultural y el Bienestar de Inmigrantes}

\begin{abstract}
Resumen
El presente estudio objetivó evaluar la relación predictiva de variables sociodemográficas, adaptación cultural y esperanza sobre el bienestar general (BEG), subjetivo (BES), social (BESo) y psicológico (BEP) y en el sentido de la vida. Participaron 108 inmigrantes. Los instrumentos utilizados fueron: cuestionario biossociodemográfico, Mental Health Continuum - Short Form, Escala de Esperanza, Acculturation Measures y Cuestionario de Sentido de la Vida. En general, solo la adaptación sociocultural mostró una relación predictiva positiva con todos los tipos de bienestar estudiados, además de una relación predictiva negativa con la presencia de sentido de vida. La adaptación psicológica solamente se relaciona de manera predictiva y positiva con el BES. La percepción de distancia cultural afectó negativamente al BESo. La presencia de sentido de vida fue predicha negativamente por el tipo de inmigración y edad. La búsqueda por sentido fue predicha negativamente por los ingresos. Los resultados son importantes para una mejor comprensión de los factores que influyen en la experiencia de los inmigrantes en Brasil. Palabras clave: inmigración brasileña; factores socioculturales; refugiados; psicología positiva.
\end{abstract}

\section{Introduction}

The global migration crisis has intensified the flow of immigrants in Brazil. Between 2000 and July 2018, approximately 1.1 million immigrants entered Brazil (Cavalcanti, Oliveira, \& Macedo, 2018). However, even in the face of this situation, scientific studies on the subject are scarce, and are concentrated in the area of law (Aydos, Baeninger, \& Dominguez, 2008).
The immigration process can be divided into two stages: pre and post-migration. Pre migration is intended for mental organization for change and can contain stressors, depending on how they deal with the impending country reestablishment (Mahonen \& Jasinskaja-Lahti, 2012). Pre-migration can influence post-migration, facilitating psychological adjustment and adaptation to the new culture (Mahonen \& Jasinskaja-Lahti, 2012). 
Post-migration occurs after arriving in the chosen country, consisting of adapting to the local culture (Tempany, 2009). This period can cause distress to the subject, comparing life in the home country, in the absence of social support (World Health Organization \& United Nations High Commissioner for Refugees, 2015).

Lack of skills valued in the culture that greets it such as speaking the language or mastering an important economic activity for the country, can cause discomfort (Ryan, Dooley, \& Benson, 2008). Bureaucratic barriers, such as validation of diplomas and professional credentials for reintegration into the labor market, hinders the search for a fresh start (Krahn, Derwing, Mulder, \& Wilkinson, 2000; Vinokurov, Trickett, \& Birman, 2017).

Adjustment to the new country can occurs in many ways by connecting with the new culture or maintaining original culture heritage (Güngör \& Perdu, 2017; Schwartz et al., 2013). Several factors can influence cultural adaptation, such as psychological and socio-cultural adaptation and acculturation (Demes \& Geeraert, 2014). Sociocultural adaptation refers to the mechanisms for accessing the new culture (Demes \& Geeraert, 2014). On the other hand, psychological adaptation concerns emotional and affective factors, reflecting how the immigrant feels with the new culture, presenting a relationship with well-being (Demes $\&$ Geeraert, 2014).

The process of acculturation consists of changes related to the contact with the new culture, how much they maintain their cultural heritage and if they accept the new reality (Birman, Simon, Chan, \& Tran, 2014; Demes \& Geeraert, 2014). Context and situation are important to define when and what type of acculturation is more beneficial (Birman et al., 2014; Schwartz et al., 2013). In order to obtain employment in a compatible position with the one they had in their country, the absorption of local customs is more relevant (Birman et al., 2014; Salo \& Birman, 2015). However, the social support that was noticed can generate contact with pairs from the country of origin, creating a relationship network and, consequently, preserving their cultural heritage (Birman et al., 2014; Vinokurov et.al, 2017).

Immigrant relationships can influence the process of cultural adaptation and can impact their level of well-being (Güngör \& Perdu, 2017). According to World Health Organization (WHO), mental health does not qualify as just an absence of mental illness, but as a state of well-being in which the individual realizes his own potential, deals with the normal stress of life and contributes to the community (Machado \& Bandeira, 2015). The Mental Health Continuum studies both virtues that generate well-being in individuals and also, mental health indicators (Keyes et al., 2008; Keyes, 2007).

The theory points out that healthy human functioning can be evaluated by three factors: subjective, psychological and social well-being (Keyes, 2002). Subjective well-being can be considered the individual's assessment of his own life (Kesebir \& Diener, 2008) looking for emotional responses, judgment about life satisfaction and presence of positive and negative affections (Diener, Oishi, \& Lucas 2015; Keyes, 2002).

Psychological well-being is based on eudaimonism, coined by Aristotle, which consists of the need to find personal virtue and with it, walk your own path with a purpose (Ryff, 2013). Psychological well-being consists of six facets, which are: self-acceptance, personal growth, autonomy, positive realtionships, environmental mastery and purpose in life (Ryff, 1989, 2013). Social well-being refers to how the subject interacts, evaluates and behaves in the face of a circumstance within society, since life involves other factors besides the relationship with yourself (Keyes, 1998). Social well-being is divided into social integration, social acceptance, social contribution, social actualization and social coherence (Keyes, 1998).

Some studies (Ai, Tice, Whitsett, Ishisaka, \& Chim, 2007; Jani, Underwood, \& Ranweiller 2015; Satici, 2016; Steger, 2012) have shown that external variables such as hope and meaning of life influence well-being. Hope is a motivational state based on the sense of success as a result from the interaction between two facets, agency and routes. Agency is the energy focused on targeted objectives (Snyder et al., 1991). Routes are the paths that are found to plan and achieve these objectives (Snyder, et al., 1991). Hopeful people reach their goals more easily, as they develop routes for this, producing grater satisfaction with life (Hutz, Midgett, Pacico, Bastianello, \& Zanon, 2014). Therefore, having a goal to strive for can positively influence well-being (Green, Oades \& Grant, 2006).

Hope and meaning of life can be directly related, since thoughts directed to an objective, which are part of the theory of hope, are at the heart of the theories of meaning of life (Feldman \& Snyder, 2005). This construct can be understood as a dimension in which a person sees significance in his own life, as he realizes he has a purpose, a mission or a general objective (Steger, 2009). The study of the meaning of life includes the 
understanding of the subjective experience of human beings and what makes life meaningful (Martela \& Steger, 2016). It is important to emphasize that the construct of meaning of life can be divided in two aspects: the search for meaning and the presence of meaning.

The search for meaning can be an indicator of well-being and psychopathology (Steger, Frazier, Oishi, \& Kaler, 2006) and can be defined as the desire and effort to establish and/or increase the understanding about significance and purpose of life (Steger, 2009). While some struggle for the minimum meaning of life, others live life with meaning and continue to seek a deeper sense constantly (Steger, 2009). The search for meaning is associated with higher levels of neuroticism, depression, negative affection and anxiety (Steger et al., 2006). Even though people who seek meaning in life tend to feel more unsatisfied with themselves and less control of the environment around them, it is also related to be more open minded (Steger, Kashdan, Sullivan, \& Lorentz, 2008). On the other hand, the presence of meaning consists of how much the individual judges his own life meaningful (Steger et al., 2006) and indicates positive relationships with emotions, life satisfaction, self-esteem and negatives relationships with depression (Kleiman \& Beaver, 2013; Steger et al., 2006).

The way studies have been done about immigrants, for the most part, highlights traumas and their consequences (Miller et al., 2002). On the other hand, to understand the virtues and how to reframe and overcome specific situations is also extremely important (Ai et al., 2003; Ai et al., 2005). In addition, as previously explained, the wave of immigration in Brazil is growing and, although there are several international studies about the subject, Brazilian scientific studies are scarce and centralized on the area of law (Aydos, Baeninger, \& Dominguez, 2008). Consequently, this study has the main objective of verifying to what extent sociodemographic and psychological variables, such as hope and cultural adaptation, are related in a predictive way with the different types of well-being and meaning of life, for the immigrant.

\section{Method}

\section{Participants}

The sample consisted of 108 immigrants, which was divided into two categories: constrained immigrants and immigrants in general. Constrained immigrants are all those who have been forced to immigrate to Brazil because they had no alternative to survive in their countries of residence. Additionally, immigrants in general are those who chose to immigrate to Brazil for reasons such as: identification with culture, study, health, among others.

The criteria for inclusion of the participants referred to the explicit and free will to participate in the research, to be over 18 years old and to be an immigrant residing in Brazil. Table 1 has more information about the sample.

\section{Instruments}

Sociodemographic Questionnaire. Versions in Portuguese, English, Spanish and French were used. This instrument aims to collect sociodemographic information, with aspects related to the type of immigration, gender, marital status, place of birth and residence, age, family constitution, income, religion, dwelling time, job, job satisfaction, education level, etc.

Mental Health Continuum - Short Form (MHCSF - Keyes, 2005). The instrument was used in: Brazilian Portuguese (adapted by Machado \& Bandeira, 2015), English (original version by Keyes, 2005), Spanish (adapted by Echeverría et al., 2017) and French (adapted by Dore, OLughlin, Sabiston \& Fournier, 2016) and consists of 14 items, answered by a six point Likert scale type $(1=$ never; $6=$ everyday). The scale consists of three subscales, subjective well-being (three items), social well-being (five items) and psychologic well-being (six items). In the present study, the reliability of both the general scale and the subscales was greater than $\alpha=0.86$.

Dispositional Hope Scale (Snnyder et al. 1991). The instrument was used in: Brazilian Portuguese (adapted by Pacico, 2011), English (original version by Snyder et al., 1991), Spanish (adapted by Galiana, Oliver, Sancho, \& Tomás, 2015) and French (adapted by Gana, Daigre, \& Ledrich, 2013) and consists of 8 items, answered by an eight- point Likert scale type (1 $=$ totally false; $8=$ totally true). The scale consists of two factors, Agency and Routes. In the present study, the reliability of the general scale and the two factors was greater than $\alpha=0.91$.

Acculturation Measures (Demes \& Geeraert, 2014). This instrument was adapted for several languages, including Portuguese, English, Spanish and French, by the creator of the scale. It is an instrument developed to measure the cultural adaptation and acculturation of immigrants from different countries through 40 items in total. The instrument consists 
Table 1.

Sociodemographic data of the sample from study 2

\begin{tabular}{|c|c|c|c|}
\hline & Total & Immigrants in general & Constrained Immigrants \\
\hline Variable & $\mathrm{N}=108$ & $\mathrm{n}=76(70.4 \%)$ & $\mathrm{n}=32(29.6 \%)$ \\
\hline Age M (DP) & $39.13(13.72)$ & $42.79(14.26)$ & $30.44(6.82)$ \\
\hline Range of age & $18-89$ & $20-89$ & $18-46$ \\
\hline Gender & $N(\%)$ & $n(\%)$ & $n(\%)$ \\
\hline Female & $58(53.7 \%)$ & $45(59.2 \%)$ & $13(40.6 \%)$ \\
\hline Male & $50(46.3 \%)$ & $31(40.8 \%)$ & $19(59.4 \%)$ \\
\hline \multicolumn{4}{|l|}{ Language } \\
\hline Portuguese & $33(30.6 \%)$ & $24(31.6 \%)$ & $9(28.1 \%)$ \\
\hline Spanish & $41(38.0 \%)$ & $21(27.6 \%)$ & $20(90.6 \%)$ \\
\hline French & $18(16.7 \%)$ & $15(19.7 \%)$ & $3(9.4 \%)$ \\
\hline English & $16(14.8 \%)$ & $16(21.1 \%)$ & $0(0.0 \%)$ \\
\hline \multicolumn{4}{|l|}{ Income } \\
\hline Up to 1 minimum wage & $27(25.0 \%)$ & $11(14.5 \%)$ & $16(50.0 \%)$ \\
\hline From 1 to 3 minimum wage & $37(34.3 \%)$ & $21(27.6 \%)$ & $16(50.0 \%)$ \\
\hline From 3 to 5 minimum wage & $16(14.8 \%)$ & $16(21.1 \%)$ & $0(0.0 \%)$ \\
\hline From 5 to 8 minimum wage & $9(8.3 \%)$ & $9(11.8 \%)$ & $0(0.0 \%)$ \\
\hline More than 8 minimum wage & $19(17.6 \%)$ & $19(25.0 \%)$ & $0(0.0 \%)$ \\
\hline \multicolumn{4}{|c|}{ Immigrated with someone in the family } \\
\hline Yes & $40(37.0 \%)$ & $21(27.6 \%)$ & $19(59.4 \%)$ \\
\hline No & $68(63.0 \%)$ & $55(72.4 \%)$ & $13(40.6 \%)$ \\
\hline \multicolumn{4}{|l|}{ Region of Origin } \\
\hline Africa & $4(3.7 \%)$ & $1(1.3 \%)$ & $3(9.4 \%)$ \\
\hline North America & $7(6.5 \%)$ & $7(9.2 \%)$ & $0(0 \%)$ \\
\hline Latin America & $61(56.5 \%)$ & $33(43.4 \%)$ & $28(87.5 \%)$ \\
\hline Europe & $34(31.5 \%)$ & $34(44.7 \%)$ & $0(0.0 \%)$ \\
\hline Middle East & $2(1.8 \%)$ & $1(1.3 \%)$ & $1(3.1 \%)$ \\
\hline
\end{tabular}

of four scales: Brief Sociocultural Adaptation Scale (BSAS) with twelve items, answered by a seven-point Likert scale type ( 1 = very difficult; $7=$ very easy $)$ that analyses sociocultural adaptation, a Brief Psychological Adaptation Scale (BPAS) with eight items, answered by a seven-point Likert scale type $(1=$ never; 7 = always $)$ that analyses the psychological adaptation, a Brief Perceived Cultural Distance Scale (BPCDS) with twelve items, answered by a seven-point Likert scale type (1 $=$ very similar; $7=$ very different $)$ that analyses the perception of cultural distance and the Brief Acculturation Orientation Scale (BAOS) which is divided in two, the first consists of acculturation for the home country with four items and the second, acculturation for the host country with four items, answered by a seven-point Likert scale type $(1=$ strongly disagree; 7 = strongly agree). In the present study, the reliability of all the subscales was greater than $\alpha=0.69$.

Meaning of Life Questionnaire (MLQ, Steger et al., 2006). The instrument was used in: Brazilian 
Portuguese (adapted by Damásio \& Koller, 2015); English (original version from Steger et al., 2006), Spanish (adapted by Steger, Frazier \& Zacchanini, 2008) and French (reverse translation by native speakers as part of the International Wellbeing Study - IWS, 2009). The scale has 10 items, answered by a seven-point Likert scale type $(1=$ totally false difficult; 7 = totally true $)$. The instrument consists of two factors, presence of meaning (five items) and search for meaning (five items). In the present study, the reliability of the two subscales was greater than $\alpha=0.86$.

\section{Procedures}

The collection took place in a virtual and in-person way. The virtual collection was carried out through the SurveyMonkey platform, including 6 constrained immigrants and 73 immigrants in general. The faceto-face version was made through the application of questionnaires in a religious institution that welcomes immigrants in the state of São Paulo, including 26 constrained immigrants and 3 immigrants in general.

The confidentiality and secrecy about the identity of the participants were guaranteed and explicitly indicated in the Terms of Free and Informed Consent, that was in compliance with the National Health Council's guideline 466/12 and 510/16. The study was approved by the Research Ethics Committee of (Information taken from the Magazine) in 2018.

\section{Data Analysis}

Hierarchical multiple linear regression procedures were performed to test the predictive relationship of sociodemographic variables (block 1) and psychological variables (block 2) about well-being levels (subjective, social, psychological and general) of search and presence of meaning. In block 1 , the variables type of immigration were used (immigrant in general $=1$; constrained immigrant $=2$ ), dwelling time, if immigrated with someone in the family (yes $=1$; no $=2$ ), income (up to a minimum wage $=1$; from 1 to 3 minimum wages $=2$; from 3 to 5 minimum wages $=3$; from 5 to 8 minimum wages $=4$; more than 8 minimum wages $=5$ ), gender (female $=1$; male $=2$ ) and age. Block 2 used the variables: socio-cultural and psychological adaptation, perceived cultural distance, acculturation of the native country and form the host country and hope (agency and routes).

For the hierarchical multiple linear regression analyses, resampling procedures were implemented (bootstrapping; 1000 resampling, with a 99\% confidence interval). The determination coefficient of the multiple linear regression was calculated with the $R^{2}$.

\section{Results}

Regarding general well-being, only block 2 was statistically significant $(F(13,94)=5.68, p<0.001)$. Sociocultural adaptation was the only positive predictor variable of general well-being. No multicollinearity was found that compromised the analyses (Table 2).

Regarding subjective well-being, both block 1 $(F(6,101)=2.48, p<0.05)$ and block $2(F(13,94)=$ $3.59, p<0.001)$ were statistically significant. The gender variable was marginal and negatively significant. On the other hand, socio-cultural and psychological adaptation prove to be positive predictors of subjective well-being. No multicollinearity was found that compromised the analyses (Table 3).

Regarding social well-being, only block 2 was statistically significant $(F(13,94)=5.44, p<0.001)$. Sociocultural adaptation and the perceived cultural distance were the only variables that proved to be positive predictors of social well-being. No multicollinearity was found that compromised the analyses (Table 4).

Regarding psychological well-being, only block 2 was statistically significant $(F(13,94)=2.60, p<$ $0.005)$. Sociocultural adaptation was the only variable that proved to be positive predictor of psychological well-being. No multicollinearity was found that compromised the analyses (Table 5).

Regarding the presence of meaning in life, both block $1(F(6,101)=5.11, p<0.05)$ and block $2(F(13$, 94) $=4.17, p<0.05)$ were statistically significant. The type of immigration, age and sociocultural adaptation proved to be negative predictors of presence of meaning in life. No multicollinearity was found that compromised the analyses (Table 6).

Regarding the search of meaning in life, both block $1(F(6,101)=3.11, p<0.01)$ and block $2(F(13$, $94)=1.84, p<0.05)$ were statistically significant. Only income proved to be a positive variable predictor of search of meaning in life. No multicollinearity was found that compromised the analyses (Table 7).

\section{Discussion}

Sociocultural adaptation was the only predictor in common for the four types of well-being (general, subjective, social and psychological), since this relationship was previously demonstrated by other studies (Demes 
Table 2.

Coefficients of multiple linear regression with general well-being as a dependent variable

\begin{tabular}{|c|c|c|c|c|c|c|c|}
\hline & Independent variables & $\beta$ & $\mathrm{t}$ & $\mathrm{p}$ & Tolerance & VIF & $\mathrm{R}^{2}$ \\
\hline \multirow{7}{*}{ Block 1} & Constant & & 4.612 & 0.000 & & & \multirow{7}{*}{$11 \%$} \\
\hline & Type of Immigration & 0.157 & 1.234 & 0.220 & 0.542 & 1.845 & \\
\hline & Time in Brazil & 0.016 & 0.131 & 0.896 & 0.582 & 1.717 & \\
\hline & $\begin{array}{l}\text { Immigrated with someone in the } \\
\text { family }\end{array}$ & -0.192 & -1.895 & 0.061 & 0.855 & 1.170 & \\
\hline & Income & 0.038 & 0.327 & 0.744 & 0.647 & 1.545 & \\
\hline & Gender & -0.093 & -0.935 & 0.352 & 0.891 & 1.122 & \\
\hline & Age & 0.220 & 1.592 & 0.115 & 0.463 & 2.160 & \\
\hline \multirow{14}{*}{ Block 2} & Constant & & -0.364 & 0.717 & & & \multirow{14}{*}{$44 \%$} \\
\hline & Type of Immigration & 0.188 & 1.706 & 0.091 & 0.489 & 2.047 & \\
\hline & Time in Brazil & -0.058 & -0.515 & 0.608 & 0.464 & 2.157 & \\
\hline & $\begin{array}{l}\text { Immigrated with someone in the } \\
\text { family }\end{array}$ & -0.116 & -1.348 & 0.181 & 0.807 & 1.240 & \\
\hline & Income & 0.068 & 0.646 & 0.520 & 0.542 & 1.845 & \\
\hline & Gender & -0.146 & -1.676 & 0.097 & 0.786 & 1.272 & \\
\hline & Age & 0.202 & 1.722 & 0.088 & 0.433 & 2.310 & \\
\hline & Sociocultural Adaptation & 0.445 & 3.994 & $0.000^{*}$ & 0.479 & 2.087 & \\
\hline & Psychological Adaptation & 0.148 & 1.454 & 0.149 & 0.578 & 1.729 & \\
\hline & Perceived Cultural Distance & -0.078 & -0.811 & 0.419 & 0.649 & 1.541 & \\
\hline & Home country Acculturation & 0.134 & 1.525 & 0.131 & 0.776 & 1.289 & \\
\hline & Brazil Acculturation & 0.023 & 0.256 & 0.799 & 0.715 & 1.398 & \\
\hline & Routes & 0.051 & 0.386 & 0.701 & 0.343 & 2.914 & \\
\hline & Agency & 0.067 & 0.490 & 0.625 & 0.319 & 3.138 & \\
\hline
\end{tabular}

${ }^{*} p<0.05,{ }^{* *} p<0.001$

\& Geeraert, 2014; Mähonen \& Jasinskaja-Lahti, 2012; O'Reilly, Ryan \& Hickey, 2010;). The more mechanisms to adapt to the new way of life, the greater the levels of well-being will be experienced. When an immigrant is able to speak the local language, work, participate in a support network and has contact with immigrants in the same situation, allows him the experience of a positive sociocultural adaptation (O'Reilly et al., 2010). In this way, he will feel able to deal with his own problems, more satisfied with life and himself, part of the community where he lives and playing a relevant role in it.

Sociocultural adaptation also impacted the presence of meaning, but in a negative way. To access a new culture, it is necessary that the individual be open to understand their values and beliefs (Demes \& Geeraert, 2014). However, this may involve a detachment from his own culture (Beiser \& Hou, 2017; Demes \& Geeraert, 2014), and may cause doubts about the meaning of his own life.

Also, psychological adaptation was only a predictor of subjective well-being. Unlike to what was expected (Demes \& Geeraert, 2014), general and psychological well-being were not impacted by this variable. One hypothesis for this result is the proximity between the theory of subjective well-being and psychological adaptation. Both concepts involve 
Table 3.

Coefficients of multiple linear regression with subjective well-being as a dependent variable

\begin{tabular}{|c|c|c|c|c|c|c|c|}
\hline & Independent variables & $\beta$ & $\mathrm{t}$ & $\mathrm{p}$ & Tolerance & VIF & $\mathrm{R}^{2}$ \\
\hline \multirow{7}{*}{ Block 1} & Constant & & 4.788 & $0.000^{* *}$ & & & \multirow{7}{*}{$13 \%$} \\
\hline & Type of immigration & 0.135 & 1.066 & 0.289 & 0.542 & 1.845 & \\
\hline & Time in Brazil & 0.047 & 0.384 & 0.701 & 0.582 & 1.717 & \\
\hline & Immigrated with someone in the family & -0.188 & -1.869 & 0.065 & 0.855 & 1.170 & \\
\hline & Income & 0.023 & 0.202 & 0.840 & 0.647 & 1.545 & \\
\hline & Gender & -0.188 & -1.912 & 0.059 & 0.891 & 1.122 & \\
\hline & Age & 0.210 & 1.537 & 0.127 & 0.463 & 2.160 & \\
\hline \multirow{14}{*}{ Block 2} & Constant & & 0.071 & 0.943 & & & \multirow{14}{*}{$33 \%$} \\
\hline & Type of immigration & 0.152 & 1.259 & 0.211 & 0.489 & 2.047 & \\
\hline & Time in Brazil & 0.030 & 0.240 & 0.811 & 0.464 & 2.157 & \\
\hline & Immigrated with someone in the family & -0.126 & -1.340 & 0.183 & 0.807 & 1.240 & \\
\hline & Income & 0.011 & 0.093 & 0.926 & 0.542 & 1.845 & \\
\hline & Gender & -0.186 & -1.958 & 0.053 & 0.786 & 1.272 & \\
\hline & Age & 0.161 & 1.258 & 0.212 & 0.433 & 2.310 & \\
\hline & Sociocultural Adaptation & 0.248 & 2.035 & $0.045^{*}$ & 0.479 & 2.087 & \\
\hline & Psychological Adaptation & 0.239 & 2.157 & $0.034^{*}$ & 0.578 & 1.729 & \\
\hline & Perceived Cultural Distance & -0.039 & -0.376 & 0.708 & 0.649 & 1.541 & \\
\hline & Home country Acculturation & 0.129 & 1.344 & 0.182 & 0.776 & 1.289 & \\
\hline & Brazil Acculturation & -0.001 & -0.006 & 0.995 & 0.715 & 1.398 & \\
\hline & Routes & -0.015 & -0.102 & 0.919 & 0.343 & 2.914 & \\
\hline & Agency & 0.171 & 1.147 & 0.254 & 0.319 & 3.138 & \\
\hline
\end{tabular}

${ }^{*} p<0.05 * * p<0.001$

satisfaction with your own life, unlike psychological and general well-being.

Regarding the gender variable, men showed marginally less subjective well-being than women. This converges with previous results, which indicates that is no substantial difference in the levels of subjective well-being between men and women (Diener \& Ryan, 2009).

Another result that converges with previous findings is the perception of proximity between the native culture and the host country, which can raise levels of social well-being (Demes \& Geeraert, 2014). The greater proximity between the two cultures can facilitate the perception of integration with the community. The immigrant can feel that he really participates in that society and that his presence matters. The perception of distance or proximity to a culture can complicate or facilitate sociocultural adaptation (Demes \& Geeraert, 2014). An immigrant from a culture more similar than Brazilian culture, such as Latin America, tends to present more resources to understand and access Brazilian culture. These immigrants were able to have a better understanding regarding the functioning of society and its rules, and, consequently, they will feel that they make sense and they fit.

Regarding to the type of immigration, constrained immigrants tend to show lower levels of presence of meaning in life than immigrants in general. Constrained immigrants may have doubts concerning their sense of life because they have suffered disorientation of the cultural and family system, which can lead to family separation or even the ethnic community (Ciobanu, 
Table 4.

Coefficients of multiple linear regression with subjective well-being as a dependent variable

\begin{tabular}{|c|c|c|c|c|c|c|c|}
\hline & Independent variables & $\beta$ & $\mathrm{t}$ & $\mathrm{p}$ & Tolerance & VIF & $\mathrm{R}^{2}$ \\
\hline \multirow{7}{*}{ Block 1} & Constant & & 2.148 & $0.034 *$ & & & \multirow{7}{*}{$10 \%$} \\
\hline & Type of immigration & 0.174 & 1.355 & 0.178 & 0.542 & 1.845 & \\
\hline & Time in Brazil & 0.023 & 0.186 & 0.853 & 0.582 & 1.717 & \\
\hline & Immigrated with someone in the family & -0.177 & -1.729 & 0.087 & 0.855 & 1.170 & \\
\hline & Income & -0.021 & -0.179 & 0.859 & 0.647 & 1.545 & \\
\hline & Gender & -0.016 & -0.163 & 0.871 & 0.891 & 1.122 & \\
\hline & Age & 0.183 & 1.315 & 0.191 & 0.463 & 2.160 & \\
\hline \multirow{14}{*}{ Block 2} & Constant & & -1.207 & 0.231 & & & \multirow{14}{*}{$43 \%$} \\
\hline & Type of immigration & 0.163 & 1.466 & 0.146 & 0.489 & 2.047 & \\
\hline & Time in Brazil & -0.095 & -0.833 & 0.407 & 0.464 & 2.157 & \\
\hline & Immigrated with someone in the family & -0.075 & -0.869 & 0.387 & 0.807 & 1.240 & \\
\hline & Income & 0.003 & 0.030 & 0.976 & 0.542 & 1.845 & \\
\hline & Gender & -0.055 & -0.627 & 0.532 & 0.786 & 1.272 & \\
\hline & Age & 0.193 & 1.632 & 0.106 & 0.433 & 2.310 & \\
\hline & Sociocultural Adaptation & 0.298 & 2.644 & $0.010^{*}$ & 0.479 & 2.087 & \\
\hline & Psychological Adaptation & 0.199 & 1.944 & 0.055 & 0.578 & 1.729 & \\
\hline & Perceived Cultural Distance & -0.205 & -2.114 & $0.037^{*}$ & 0.649 & 1.541 & \\
\hline & Home country Acculturation & 0.160 & 1.810 & 0.074 & 0.776 & 1.289 & \\
\hline & Brazil Acculturation & 0.091 & 0.989 & 0.325 & 0.715 & 1.398 & \\
\hline & Routes & 0.106 & 0.795 & 0.429 & 0.343 & 2.914 & \\
\hline & Agency & -0.039 & -0.283 & 0.778 & 0.319 & 3.138 & \\
\hline
\end{tabular}

${ }^{*} p<0.05,{ }^{* *} p<0.001$

Fokkema, \& Nedelcu 2016; Schweitzer, Melville, Steel, $\&$ Lacherez 2006). The difficulty of professional placement can also influence the feeling of lack of purpose in the daily lives of constrained immigrants (Miller et al., 2002). This immigration presents more difficulties in pre-migration, and there may be traumas and risk situations that immigrants in general did not have to go through to immigrate (Galina, Silva, Haydu, \& Martin, 2017; Refugee Reintegration Institute, 2016; Jani et al., 2015; Martins-Borges, 2013). For this reason, the meaning of life can be shaken and will be rethought when arriving in Brazil. Another possible explanation may be the fact that the collection was carried out in a religious institution. The sense of meaning in life can be found by religion (Krause, Hill, \& Ironson, 2019), being embraced by a religious institution, even if it is not mandatory to follow the same philosophy, can influence the perception of the sense of life by immigrants.

Different from the expected (Steger, Oishi \& Kashdan, 2009), younger people describe higher levels of presence of sense in life than older people. An older immigrant may show more difficulties immigrating than younger ones, such as, proficiency in the local language, professional relocation and the health conditions encountered (Beiser \& Hou, 2017; Ciobanu et al., 2016). The older a person is when immigrating, the less will be the identification with the host country (Beiser \& Hou, 2017). This can disrupt the structure of the older person and change the view of the meaning of life.

For the search of meaning in life, income had a negative impact. The more the immigrant seeks meaning in his life, the lower is his income. This result may be 
Table 5.

Coefficients of multiple linear regression with psychological well-being as a dependent variable

\begin{tabular}{|c|c|c|c|c|c|c|c|}
\hline & Independent variables & $\beta$ & $\mathrm{t}$ & $\mathrm{p}$ & Tolerance & VIF & $\mathrm{R}^{2}$ \\
\hline \multirow{7}{*}{ Block 1} & Constant & & 4.997 & $0.000^{*}$ & & & \multirow{7}{*}{$6 \%$} \\
\hline & Type of immigration & 0.084 & 0.637 & 0.526 & 0.542 & 1.845 & \\
\hline & Time in Brazil & -0.016 & -0.124 & 0.901 & 0.582 & 1.717 & \\
\hline & $\begin{array}{l}\text { Immigrated with someone in the } \\
\text { family }\end{array}$ & -0.127 & -1.221 & 0.225 & 0.855 & 1.170 & \\
\hline & Income & 0.093 & 0.776 & 0.439 & 0.647 & 1.545 & \\
\hline & Gender & -0.08 & -0.786 & 0.434 & 0.891 & 1.122 & \\
\hline & Age & 0.168 & 1.187 & 0.238 & 0.463 & 2.160 & \\
\hline \multirow{14}{*}{ Block 2} & Constant & & 0.399 & 0.691 & & & \multirow{14}{*}{$27 \%$} \\
\hline & Type of immigration & 0.154 & 1.213 & 0.228 & 0.489 & 2.047 & \\
\hline & Time in Brazil & -0.043 & -0.333 & 0.74 & 0.464 & 2.157 & \\
\hline & $\begin{array}{l}\text { Immigrated with someone in the } \\
\text { family }\end{array}$ & -0.103 & -1.044 & 0.299 & 0.807 & 1.240 & \\
\hline & Income & 0.139 & 1.159 & 0.249 & 0.542 & 1.845 & \\
\hline & Gender & -0.156 & -1.568 & 0.12 & 0.786 & 1.272 & \\
\hline & Age & 0.146 & 1.089 & 0.279 & 0.433 & 2.310 & \\
\hline & Sociocultural Adaptation & 0.52 & 4.073 & $0.000^{*}$ & 0.479 & 2.087 & \\
\hline & Psychological Adaptation & -0.024 & -0.203 & 0.84 & 0.578 & 1.729 & \\
\hline & Perceived Cultural Distance & 0.07 & 0.636 & 0.527 & 0.649 & 1.541 & \\
\hline & Home country Acculturation & 0.05 & 0.498 & 0.619 & 0.776 & 1.289 & \\
\hline & Brazil Acculturation & -0.046 & -0.436 & 0.664 & 0.715 & 1.398 & \\
\hline & Routes & 0.007 & 0.047 & 0.963 & 0.343 & 2.914 & \\
\hline & Agency & 0.092 & 0.587 & 0.559 & 0.319 & 3.138 & \\
\hline
\end{tabular}

${ }^{*} p<0.05,{ }^{*} p<0.001$

related to dissatisfaction with himself and with the surrounding environment (Steger, et al., 2008), which can lead to the constant search for his purpose of life. The growth in the search for meaning can be faced when immigrating, since the immigrant needs to reframe several concepts that, perhaps, come into conflict with Brazilian culture. Lower income can lead to disappointment with current life, causing immigrants to question and seek a new meaning for their life.

Different from the expected (Güngör \& Perdu, 2017; Mähonen \& Jasinskaja-Lahti, 2012), the acculturation variable did not impact any type of well-being. As the context and situation in which immigrants find themselves are very important (Birman et al., 2014; Schwartz et al., 2013), it is possible to hypothesize that the large number of Latin immigrants in the sample influenced the result. Even though neighboring countries have different cultures from Brazil, many customs, ways of thinking and economic difficulties are present in all these territories, which can lead to a familiarity with Brazilian culture and a better insertion of this immigrant in Brazil, without needing to give up the culture of Brazil or from his country.

When it comes to hope, this variable was not a predictor of any analyzed outcome. Immigrants may lose their sense of hope among the psychological and physical turbulence they have experienced (Ai et al., 2007) and/or for the lack of social support (Goodman, 2004). In the case of the present study, it is not possible to assure that, necessarily, immigrants lost their sense of hope, but it did not prove to be relevant. Immigrants had to adapt to the new reality and the way of living in Brazilian culture. Therefore, hope ended up not being so relevant for immigrants among 
Table 6.

Coefficients of multiple linear regression with presence of meaning of life as a dependent variable

\begin{tabular}{|c|c|c|c|c|c|c|c|}
\hline & Independent variables & $B$ & $\mathrm{t}$ & $\mathrm{p}$ & Tolerance & VIF & $\mathrm{R}^{2}$ \\
\hline \multirow{7}{*}{ Block 1} & Constant & & 8.507 & $0.000 * *$ & & & \multirow{7}{*}{$23 \%$} \\
\hline & Type of immigration & -0.418 & -3.533 & $0.001 *$ & 0.542 & 1.845 & \\
\hline & Time in Brazil & -0.018 & -0.154 & 0.878 & 0.582 & 1.717 & \\
\hline & $\begin{array}{l}\text { Immigrated with someone in the } \\
\text { family }\end{array}$ & 0.152 & 1.615 & 0.109 & 0.855 & 1.170 & \\
\hline & Income & -0.105 & -0.974 & 0.332 & 0.647 & 1.545 & \\
\hline & Gender & 0.138 & 1.491 & 0.139 & 0.891 & 1.122 & \\
\hline & Age & -0.339 & -2.649 & $0.009 *$ & 0.463 & 2.160 & \\
\hline \multirow{14}{*}{ Block 2} & Constant & & 7.142 & $0.000 * *$ & & & \multirow{14}{*}{$37 \%$} \\
\hline & Type of immigration & -0.502 & -4.274 & $0.000 * *$ & 0.489 & 2.047 & \\
\hline & Time in Brazil & -0.080 & -0.664 & 0.508 & 0.464 & 2.157 & \\
\hline & $\begin{array}{l}\text { Immigrated with someone in the } \\
\text { family }\end{array}$ & 0.148 & 1.614 & 0.110 & 0.807 & 1.240 & \\
\hline & Income & -0.114 & -1.023 & 0.309 & 0.542 & 1.845 & \\
\hline & Gender & 0.177 & 1.914 & 0.059 & 0.786 & 1.272 & \\
\hline & Age & -0.280 & -2.244 & $0.027 *$ & 0.433 & 2.310 & \\
\hline & Sociocultural Adaptation & -0.383 & -3.225 & $0.002 *$ & 0.479 & 2.087 & \\
\hline & Psychological Adaptation & 0.009 & 0.086 & 0.931 & 0.578 & 1.729 & \\
\hline & Perceived Cultural Distance & -0.148 & -1.453 & 0.150 & 0.649 & 1.541 & \\
\hline & Home country Acculturation & 0.041 & 0.440 & 0.661 & 0.776 & 1.289 & \\
\hline & Brazil Acculturation & 0.051 & 0.528 & 0.599 & 0.715 & 1.398 & \\
\hline & Routes & -0.015 & -0.107 & 0.915 & 0.343 & 2.914 & \\
\hline & Agency & -0.187 & -1.285 & 0.202 & 0.319 & 3.138 & \\
\hline
\end{tabular}

${ }^{*} p<0.05,{ }^{* *} p<0.001$

so many factors that are necessary in the process of adaptation to Brazil.

Finally, it is important to note that in almost all cases, except in the search of meaning, the psychological variables increased the explained variance $\left(\mathrm{R}^{2}\right)$ of the dependent variables and were their main predictors. This indicates that, not only sociodemographic characteristics, but also the psychological variables studied, especially cultural adaptation, are important for the wellbeing and presence of meaning in life for immigrants.

\section{Final Considerations}

This study had some limitations, such as a lower number of participants, making it impossible to carry out more complex data analysis, like modeling by structural equation. Disregarding previous immigration may also have interfered with the participants responses, since the contact with different cultures can impact the way immigrants understand their own lives.

For future research, it would be important to analyze the length of the immigrant's permanence in Brazil and the age at which he arrived in the country, since they can influence cultural adaptation. It is expected that future studies will use larger and more diverse samples that allow deeper analysis.

This research proved to be important to understand the adaptation of the immigrant, taking into account different aspects of his life. A better understanding of cultural adaptation would benefit the 
Table 7.

Coefficients of multiple linear regression with search of meaning of life as a dependent variable

\begin{tabular}{|c|c|c|c|c|c|c|c|}
\hline & Independent variables & $\beta$ & $\mathrm{t}$ & $\mathrm{p}$ & Tolerance & VIF & $\mathrm{R}^{2}$ \\
\hline \multirow{7}{*}{ Block 1} & Constant & & 7.679 & $0.000 * *$ & & & \multirow{7}{*}{$16 \%$} \\
\hline & Type of immigration & -0.061 & -0.488 & 0.626 & 0.542 & 1.845 & \\
\hline & Time in Brazil & 0.033 & 0.273 & 0.785 & 0.582 & 1.717 & \\
\hline & $\begin{array}{l}\text { Immigrated with someone in the } \\
\text { family }\end{array}$ & -0.127 & -1.281 & 0.203 & 0.855 & 1.170 & \\
\hline & Income & -0.346 & -3.048 & $0.003^{*}$ & 0.647 & 1.545 & \\
\hline & Gender & -0.127 & -1.311 & 0.193 & 0.891 & 1.122 & \\
\hline & Age & -0.062 & -0.465 & 0.643 & 0.463 & 2.160 & \\
\hline \multirow{14}{*}{ Block 2} & Constant & & 2.547 & 0.012 & & & \multirow{14}{*}{$20 \%$} \\
\hline & Type of immigration & -0.096 & -0.73 & 0.467 & 0.489 & 2.047 & \\
\hline & Time in Brazil & 0.032 & 0.234 & 0.815 & 0.464 & 2.157 & \\
\hline & $\begin{array}{l}\text { Immigrated with someone in the } \\
\text { family }\end{array}$ & -0.101 & -0.989 & 0.325 & 0.807 & 1.240 & \\
\hline & Income & -0.388 & -3.102 & $0.003^{*}$ & 0.542 & 1.845 & \\
\hline & Gender & -0.124 & -1.199 & 0.234 & 0.786 & 1.272 & \\
\hline & Age & -0.064 & -0.46 & 0.647 & 0.433 & 2.310 & \\
\hline & Sociocultural Adaptation & 0.096 & 0.724 & 0.471 & 0.479 & 2.087 & \\
\hline & Psychological Adaptation & -0.002 & -0.018 & 0.986 & 0.578 & 1.729 & \\
\hline & Perceived Cultural Distance & 0.035 & 0.309 & 0.758 & 0.649 & 1.541 & \\
\hline & Home country Acculturation & 0.061 & 0.582 & 0.562 & 0.776 & 1.289 & \\
\hline & Brazil Acculturation & 0.172 & 1.578 & 0.118 & 0.715 & 1.398 & \\
\hline & Routes & 0.018 & 0.116 & 0.908 & 0.343 & 2.914 & \\
\hline & Agency & -0.002 & -0.01 & 0.992 & 0.319 & 3.138 & \\
\hline
\end{tabular}

${ }^{*} p<0.05,{ }^{*} p<0.001$

Brazilian and immigrant population, since would involve in deepening studies about the functioning of the Brazilian society. That way, Brazilian citizens could have a better understanding of their own society, focus on solving possible problems and value positive points.

\section{References}

Ai, A. L., Tice, N. T., Whitsett, D. D., Ishisaka, T., \& Chim, M. (2007). Posttraumatic symptoms and growth of Kosovar war refugees: The influence of hope and cognitive coping. The Journal of Positive Psychology: Dedicated to furthering research and promoting good practice, 2(1), 55-65. doi: 10.1080/17439760601069341

Aydos, M., Baeninger, R., \& Dominguez, J. A. (2008). Condições de vida da população refugiada no brasil: trajetórias migratórias e arranjos familiares. III Congresso da Associação Latino Americana de População, ALAP, Córdoba - Argentina, 24-26 de Setembro de 2008. Recuperado de: http://www.faed.udesc. br/arquivos/id_submenu/1416/artigo_sobre_refugiados_2008_mrj.pdf

Beiser, M., \& Hou, F. (2017). Predictors of positive mental health among refugees: Results from Canada's General Social Survey. Transcultural Psychiatry, 54(56), 675-695. doi: 10.1177/1363461517724985

Birman, D., Simon, C. D., Chang, W. Y., \& Tran, N. (2014). A life domains perspective on acculturation and psychological adjustment: a study of refugees from the former Soviet Union. American Journal of Community Psychology, 53(60), 60-72. doi: 10.1007/ s10464-013-9614-2 
Cavalcanti, L., Oliveira, \& T., Macedo, M. (2018). Migrações e Mercado de Trabalho no Brasil. Relatório Anual 2018. Série Migrações. Observatório das Migrações Internacionais; Ministério do Trabalho/ Conselho Nacional de Imigração e Coordenação Geral de Imigração. Brasília, DF: OBMigra. Recuperado de: http://obmigra.mte.gov.br/index.php/ relatorio-anual

Ciobanu,R.O.,Fokkema,T.,\&Nedelcu,M.(2016).Ageing as a migrant: vulnerabilities, agency and policy implications. Journal of Ethnic and Migration Studies, 43(2), 164-181. doi: 10.1080/1369183X.2016.1238903

Damásio, B. F., \& Koller, S. H. (2015). Meaning in Life Questionnaire: Adaptation process and psychometric properties of the Brazilian version. Revista Latinoamericana de Psicología, 47, 185-195. doi: 10.1016/j.rlp.2015.06.004

Demes, K. A., \& Geeraert, N. (2014). Measures matter: scales for adaptation, cultural distance, and acculturation orientation revisited. Journal of Cross-Cultural Psychology, 45(1) 91-109. doi: 10.1177/0022022113487590

Diener, E., Oishi, S., \& Lucas, R. E. (2015). National accounts of subjective well-being. American Psychologist, 70(3), 234-242. doi: 10.1037/a0038899

Diener, E., \& Ryan, K. (2009). Subjective Well-Being: A General Overview. South African Journal of Psychology, 39(4), 391-406. doi: 10.1177/008124630903900402

Dore, I., O’Loughlin, J. L., Sabiston, C. M., \& Fournier, L. (2016). Psychometric Evaluation of the Mental Health Continuum-Short Form (MHC-SF) in French Canadian Young Adults. The Canadian Journal of Psychiatry/ La Revue Canadienne de Psychiatrie, 1-9. doi: 10.1177/0706743716675855

Echeverría, G., Torres, M., Pedrals, N., Padilla, O., Rigotti, A., \& Bitran, M. (2017). Validation of a spanish version of the mental health continuumshort form questionnaire. Psicothema, 29(1), 96-102. doi: $10.7334 /$ psicothema2016.3

Feldman, D. B., \& Snyder, C. R. (2005). Hope and the meaningful life: Theoretical and empirical associations between goal-directed thinking and life meaning. Journal of Social and Clinical Psychology, 24(3), 401-421. doi: 10.1521/jscp.24.3.401.65616

Galiana, L., Oliver, A., Sancho, P., \& Tomás, J. M. (2014). Dimensionality and Validation of the
Dispositional Hope Scale in a Spanish Sample. Social Indicators Research, 120(1), 297-308. doi: 10.1007/s11205-014-0582-1

Galina, V. F., Silva, T. B. B., Haydu, M., \& Martin, D. (2017). A saúde mental dos refugiados: um olhar sobre estudos qualitativos. Interface, 21(61), 297 308. doi: 10.1590/1807-57622016.0929

Gana, K., Daigre, S., \& Ledrich, J. (2012). Psychometric properties of the french version of the adult dispositional hope scale. Assessment, 20(1), 114-119. doi: $10.1177 / 1073191112468315$

Green, L. S., Oades, L. G., \& Grant, A. M. (2006). Cognitive-behavioral, solution-focused life coaching: Enhancing goal striving, well-being, and hope. The Journal of Positive Psychology: Dedicated to furthering research and promoting good practice, 1(3), 142-149. doi: 10.1080/17439760600619849

Güngör, D., \& Perdu, N. (2017). Resilience and acculturative pathways underlying psychological well-being of immigrant. International Journal of Intercultural Relations 56, 1-12. doi: 10.1016/j. ijintrel.2016.10.005

Goodman, J. H. (2004). Coping with trauma and hardship among unaccompanied refugee youths from Sudan. Qualitative Health Research,14(9), 1177-1196. doi: $10.1177 / 1049732304265923$

Hutz, C. S., Midgett, A. M., Pacico, J. C., Bastianello, M. R., \& Zanon, C. (2014). The Relationship of Hope, Optimism, Self-Esteem, Subjective Well-Being, and Personality in Brazilians and Americans. Psychology, 5, 514-522. doi: 10.4236/psych.2014.56061

Instituto de Reintegração do Refugiado - Brasil (ADUS), (2016). Relatório ADUS 2016. Projeto Pesquisa e Conteúdo. Capítulo 7. Recuperado de: http://www.adus.org.br/ programas/projeto-pesquisa-e-conteudo/ relatorio-adus-2016/

Jani, J., Underwood, D., \& Ranweiller, J. (2015). Hope as a crucial factor in integration among unaccompanied immigrant youth in the usa: A pilot project. Journal of Integration and Migration, 17(4), 1195-1209. doi: 10.1007/s12134-015-0457-6

Jarden, A., Simpson, O., Mclachlan, K., Kashdan, T., MacKenzie, A., Jose, P. (2009). International Wellbeing Study. Recuperado de: http://www.wellbeingstudy.com/

Psico-USF, Bragança Paulista, v. 26, n. 3, p. 467-481, jul./set. 2021 
Kesebir, P., \& Diener, E. (2008). In Pursuit of Happiness: Empirical Answers to Philosophical Questions. Perspectives on Psychological Science, 3(2), 117-125. doi: 10.1111/j.1745-6916.2008.00069.x

Keyes, C. R. L. (1998). Social Well-Being. Social Psychology Quarterly, 61(2), 121-140. doi: 10.2307/2787065

Keyes, C. R. L. (2002). The Mental Health Continuum: From Languishing to Flourishing in Life. Journal of Health and Social Behavior, 43(2), 207-222. doi: $10.2307 / 3090197$

Keyes, C. L. M. (2005). The subjective well-being of America's youth: Toward a comprehensive assessment. Adolescent and Family Health, 4, 3-11.

Keyes, C. R. L. (2007). Promoting and protecting mental health as flourishing: A complementary strategy for improving national mental health. American Psychological Association, 62(2), 95-108. doi: 10.1037/0003-066X.62.2.95

Keyes, C. R. L., Wissing, M., Potgieter, J. P., Temane, M., Kruger, A., \& van Rooy, S. (2008). Evaluation of the Mental Health Continuum-Short Form (MHC-SF) in Setswana-Speaking South Africans. Clinical Psychology and Psychotherapy, 15, 181-192. doi: 10.1002/cpp.572

Kleiman, E. M., \& Beaver, J. K. (2013). A meaningful life is Worth living: Meaning in life as a suicide resiliency factor. Psychiatry Research, 210(3), 934-939. doi: 10.1016/j.psychres.2013.08.002

Krahn, H., Derwing, T., Mulder, M., \& Wilkinson, L. (2000). Educated and underemployed: Refugee integration into the canadian labour Market. Journal of International Migration and Integration/ Revue de L'integration et de la Migration Internacionale, 1(1), 5984. doi: 10.1007/s12134-000-1008-2

Krause, N., Hill, P. C., \& Ironson, G. (2019). Evaluating the relationships among religion, social virtues, and meaning in life. Archive for the Psychology of Religion, 41(1), 53-70. doi:10.1177/0084672419839797

Machado, W. L., \& Bandeira, D. R. (2015). Positive mental health: Validation of the mental health continuum - short form. Psico-USF, 20(2), 259-274. doi: 10.1590/1413-82712015200207

Mähonen, T. A., \& Jasinskaja-Lahti, I. (2012). Acculturation expectations and experiences as predictors of ethnic migrants' psychological well-being. Journal of Cross-Cultural Psychology, 44(5) 786-806. doi: 10.1177/0022022112466699

Martela, F., \& Steger, M. F. (2016): The three meanings of meaning in life: Distinguishing coherence, purpose, and significance, The Journal of Positive Psychology, 11(5), 531-545. doi: 10.1080/17439760.2015.1137623

Miller, K. E., Weine, S. M., Ramic, A., Brkic, N., Bjedic, Z. D., Smajkic, A., Boskailo, E., \& Worthington, G. (2002). The relative contribution of war experiences and exile-related stressors to levels of psychological distress among bosnian refugees. Journal of Traumatic Stress, 15(5), 377-387. doi: 10.1023/A:1020181124118

O’Reilly, A., Ryan, D., Hickey. T. (2010). The Psychological Well-Being and Sociocultural Adaptation of Short-Term International Students in Ireland. Journal of College Student Development, 51(5), 584-598. doi: $10.1353 / \operatorname{csd} .2010 .0011$

Pacico, J. C. (2011). Adaptação e Validação de Instrumentos de Avaliação de Esperança. Dissertação de Mestrado não-publicada. Curso de Pós-Graduação em Psicologia da Universidade Federal do Rio Grande do Sul. Porto Alegre.

Ryan, D., Dooley, B., \& Benson, C. (2008). Theoretical perspectives on post-migration adaptation and psychological well-being among refugees: Towards a resource-based model. Journal of Refugee Studies, 21(1), 1-18. doi: 10.1093/jrs/ fem047

Ryff, C. D. (1989). Happiness is everything or is it? explorations on the meaning of psychological wellbeing. Journal of Personality \& Social Psychology, 57(6), 1069-1081. doi: 10.1037//0022-3514.57.6.1069

Ryff, C. D. (2013). Psychological well-being revisited: Advances in the Science and practice of eudaimonia. Psychological Science, 83(1), 10-28. doi: 10.1159/000353263

Schwartz, S. J., Waterman, A. S., Umaña-Taylor, A. J., Lee, R. M., Kim, S. Y., Vazsonyi, A. T.,...Williams, M. K. (2013). Acculturation and well-being among college students from immigrant families. Journal of Clinical Psychology, 69(4), 298-318. doi: 10.1002/ jclp. 21847

Schweitzer, R., Melville, F., Steel, Z., \& Lacherez, P. (2006). Trauma, post-migration living difficulties, and social support as predictors of psychological 
adjustment in resettled Sudanese refugees. Australian and New Zealand Journal of Psychiatry, 40, 179-187. doi: 10.1111/j.1440-1614.2006.01766.x

Salo, C. D., \& Birman, D. (2015). Acculturation and psychological adjustment of vietnamese refugees: An ecological acculturation framework. American Journal of Community Psychology, 56, 395-407. doi: 10.1007/s10464-015-9760-9

Satici, S. A. (2016). Psychological vulnerability, resilience, and subjective well-being: The mediating role of hope. Personality and Individual Differences, 102, 68-73. doi: 10.1016/j.paid.2016.06.057

Snyder, C. R., Harris, C., Anderson, J. R., Holleran, S. A., Irving, L. M., Sigmon, S. T., Yoshinobu, L., Gibb, J., Langelle, C., \& Harney, P. (1991). The Will and the Ways: Development and Validation of an Individual-Differences Measure of Hope. Journal of Personality and Social Psychology, 60(4), 570-585. doi: 10.1037/0022-3514.60.4.570

Steger, M. F. (2009). Meaning in Life. In: Lopez, S.J. Oxford Handbook of Positive Psychology. (pp.679-687). Oxford: Oxford University Press.

Steger, M. F. (2012). Making Meaning in Life. Psychological Inquiry, 23, 381-385. doi: 10.1080/1047840X.2012.720832

Steger, M. F., Frazier, P., Oishi, S., \& Kaler, M. (2006). The meaning in life questionnaire: Assessing the presence of and search for meaning in life. Journal of Counseling Psychology, 53(1), 80-93. doi: 10.1037/0022-0167.53.1.80
Steger, M. F., Kashdan, T. B., Sullivan, B. A., \& Lorentz, D. (2008). Understanding the search for meaning in life: Personality, cognitive style, and the dynamic between seeking and experiencing meaning. Journal of Personality, 76(2), 199-228. doi: 10.1111/j.1467-6494.2007.00484.x

Steger, M. F., Frazier, P., \& Zacchanini, J. L. (2008). Terrorism in two cultures: Stress and growth following september 11 and the Madrid train bombings. Journal of Loss and Trauma, 13, 511-527. doi: 10.1080/15325020802173660

Tempany, M. (2009). What Research tells us about the Mental Health and Psychosocial Wellbeing of Sudanese Refugees: A Literature Review. Transcultural Psychiatry, 46(2), 300-315. doi: 10.1177/1363461509105820

Vinokurov, A., Trickett, E. J., \& Birman, D. (2017). Community context matters: Acculturation and underemployment of Russian-speaking refugees. International Journal of Intercultural Relations, 57, 4256. doi: 10.1016/j.ijintrel.2017.02.002

World Health Organization and United Nations High Commissioner for Refugees (2015). mbGAP Humanitarian Intervention Guide (mbGAP-HIG): Clinical management of mental, neurological and substance use conditions in humanitarian emergencies. Geneva: WHO.

Recebido em: 13/07/2019

Reformulado em: 10/08/2020 Aprovado em: 01/09/2020 
About the authors:

Érica Henke Garcia Martinet - Psychology Professor at Estácio de Sá University (UNESA). Psychologist from the Federal University of Rio de Janeiro (UFRJ), master's degree in Psychology from the Psychology Graduate Program at UFRJ, postgraduate degree in Logotherapy and Existential Analysis from the Catholic University of Petrópolis (UCP), graduate student in Humanist and Existential Psychology at UNESA.

E-mail: erica.henke@outlook.com

Bruno Figueiredo Damásio - Professor at the Institute of Psychology (IP) at the Federal University of Rio de Janeiro, in the Psychometry Department. Permanent Professor of the Post-Graduate Program in Psychology IP/ UFRJ. Psychologist (UEPB), master's degree and PhD in Psychology from Federal University of Rio Grande do Sul. ORCID: http://orcid.org/0000-0002-1150-092X

E-mail:bf.damasio@gmail.com

Contact:

University Estácio de Sá

Undergraduate Programe in Psychology

Av. Marechal Fontenelle, 3555, Sulacap

Rio de Janeiro-RJ, Brazil

CEP: 21740-001

Phone: (021) 4003-6767

Psico-USF, Bragança Paulista, v. 26, n. 3, p. 467-481, jul./set. 2021 